\title{
MANFAAT MEDIA DALAM PEMBELAJARAN
}

\section{Oleh:}

\author{
Isran Rasyid Karo-Karo $S^{*}$, Rohani** \\ * Dosen Tetap Jurusan Pendidikan Matematika FITK UIN-SU Medan \\ **Dosen Tetap Jurusan Pendidikan Islam Anak Usia Dini FITK UIN-SU Medan \\ *Jl. Williem Iskandar Pasar V Medan Estate \\ **Jl. Williem Iskandar Pasar V Medan Estate \\ E-mail:*isranrkaro@yahoo.com,**rohanistr@gmail.com
}

\begin{abstract}
:
Media is a tool or means as an intermediary to deliver lessons from teachers to students. Types of educational media commonly used are: graphics media, three-dimensional media, and media projection. Benefits of media in learning are: (1) Submission of subject matter can be uniformed. (2) The learning process becomes more clear and interesting. (3) The learning process becomes more interactive. (4) Efficiency in time and effort. (5) Improve the quality of student learning outcomes. (6) Media allows the learning process can be done anywhere and anytime. (7) The media can foster a positive attitude of students to the material and learning process. (8) Changing the role of teachers in a more positive and productive direction.
\end{abstract}

\section{Keywords:}

Learning media

\section{A. Pendahuluan}

Pemanfaatan media yang relevan di dalam kelas dapat mengoptimalkan proses pembelajaran. Bagi guru, media pembelajaran membantu mengkonkritkan konsep atau gagasan dan membantu memotivasi peserta belajar aktif. Bagi siswa, media dapat menjadi jembatan untuk berpikir kritis dan berbuat. Dengan demikian media dapat membantu tugas guru dan siswa untuk mencapai kompetensi dasar yang telah ditetapkam. Agar media pembelajaran dapat dimanfaatkan dengan baik, guru perlu mengetahui kebutuhan pembelajarannya dan permasalahanpermasalahan yang dihadapi siswa tentang materi yang akan diajarkan. Terkait dengan itu, media perlu dikembangkan berdasarkan relevansi, kompetensi dasar, materi dan karakteristik siswa. Guru dapat berperan sebagai kreator yaitu menciptakan dan memanfaatkan media yang tepat, efisien, dan menyenangkan bagi siswa. Namun dalam pemanfaatannya di kelas, perlu ditekankan bahwa siswalah yang seharusnya memanfaatkan media pembelajaran tersebut. Menurut paradigma behavioristik, belajar merupakan transfer pengetahuan dari expert ke novice.

Berdasarkan konsep ini, peran guru adalah menyediakan dan menuangkan informasi sebanyak-banyaknya kepada siswa. Guru mempersepsi diri berhasil dalam pekerjaannnya apabila dia dapat menuangkan pengetahuan sebanyak-banyaknya ke kepala siswa dan siswa dipersepsi berhasil apabila 
mereka tunduk menerima pengetahuan yang dituangkan guru kepada mereka. Praktek pendidikan yang berorientasi pada persepsi semacam itu adalah bersifat induktrinasi, sehingga akan berdampak pada penjinakan kognitif para siswa, menghalangi perkembangan kreativitas siswa, dan memenggal peluang siswa untuk mencapai higher order thinking.

Akhir-akhir ini, konsep belajar didekati menurut paradigma konstruktivisme. Menurut paham konstruktivistik, belajar merupakan hasil konstruksi sendiri (pebelajar) sebagai hasil interaksinya terhadap lingkungan belajar. Pengkonstruksian pemahaman dalam peristiwa belajar dapat melalui proses asimilasi atau akomodasi. Secara hakiki, asimilasi dan akomodasi terjadi sebagai usaha pembelajar untuk menyempurnakan atau merubah pengetahuan yang telah ada di benaknya (Heinich, et. al., 2002). Pengetahuan yang telah dimiliki oleh pebelajar sering pula diistilahkan sebagai prakonsepsi. Proses asimilasi terjadi apabila terdapat kesesuaian antara pengalaman baru dengan prakonsepsi yang dimiliki pebelajar. Sedangkan proses akomodasi adalah suatu proses adaptasi, evolusi, atau perubahan yang terjadi sebagai akibat pengalaman baru pebelajar yang tidak sesuai dengan prakonsepsinya.

Berdasarkan paradigma konstruktivisme tentang belajar tersebut, maka prinsip media (mediated instruction) menempati posisi cukup strategis dalam rangka mewujudkan ivent belajar secara optimal. Ivent belajar yang optimal merupakan salah satu indikator untuk mewujudkan hasil belajar peserta didik yang optimal pula. Hasil belajar yang optimal juga merupakan salah satu cerminan hasil pendidikan yang berkualitas. Pendidikan yang berkualitas memerlukan sumber daya guru yang mampu dan siap berperan secara profesional dalam lingkungan sekolah dan masyarakat (Heinich et.al., 2002; Ibrahim, 1997; Ibrahim et. al., 2001). Dalam era perkembangan Iptek yang begitu pesat dewasa ini, profesionalisme guru tidak cukup hanya dengan kemampuan membelajarkan siswa, tetapi juga harus mampu mengelola informasi dan lingkungan untuk memfasilitasi kegiatan belajar siswa (Ibrahim, et.al., 2001). Konsep lingkungan meliputi tempat belajar, metode, media, sistem penilaian, serta sarana dan prasarana yang diperlukan untuk mengemas pembelajaran dan mengatur bimbingan belajar sehingga memudahkan siswa untuk belajar. Sekaligus empati terhadap orang lain (learning to be) dan anak juga belajar untuk dapat hidup bersama orang lain (learning to live together).

Melalui permainan, anak memahami adanya aturan yang berlaku dan harus dipatuhi, sehingga anak juga belajar mengenai sebuah sistem nilai dan moral. Oleh karena itu, bermain menjadi aktivitas sentral yang sangat penting bagi anak-anak.

\section{B. Pembahasan}

\section{Pengertian Media}

Kata media berasal dari bahasa latin dan merupakan bentuk jamak dari kata medium yang secara harfiah berarti perantara atau pengantar (Sadiman, dkk, 1996) Dalam kamus besar Bahasa Indonesia (1999) media merupakan alat (sarana) komunikasi seperti koran, majalah, radio, televisi, film, poster dan spanduk. 
Sementara Danim (1995) mengemukakan media pendidikan merupakan seperangkat alat bantu atau pelengkap yang digunakan oleh guru atau pendidik dalam rangka berkomunikasi dengan siswa atau peserta didik. Sedangkan Ahmad Rohani (1997) mengatakan bahwa media adalah segala sesuatu yang dapat diindra yang berfungsi sebagai perantara/alat untuk proses komunikasi (proses belajar mengajar).

Bedasarkan pengertian-pengertian yang dikemukakan oleh para ahli tersebut di atas dapat kita ketahui bahwa media merupakan suatu alat atau sarana sebagai perantara untuk menyampaikan bahan pelajaran dari guru kepada anak didik. Menurut Heinich, dkk ((1982) yang dikutip Azhar Arsyad mengemukakan istilah medium sebagai yang mengantar informasi antara sumber dan penerima. Jadi televisi, film, foto, radio, rekaman audio, gambar yang diprokyeksikan, bahan-bahan cetakan dan sejenisnya adalah media komunikasi. Sejalan dengan itu Hamidjojo dalam Latuheru (1993) memberi batasan media sebagai semisal bentuk perantara yang digunakan oleh manusia untuk menyampaikan atau menyebar ide, gagasan atau pendapat sehingga ide, gagasan atau pendapat yang dikemukakan itu sampai kepada penerima yang dituju.

Sudjana dan Rivai (1997) mengatakan bahwa dalam metodologi pengajaran ada dua aspek yang paling menonjol yakni metode mengajar dan media pengajaran sebagai alat Bantu mengajar. Sejalan dengan itu Sudjana (1998) mengatakan bahwa alat peraga (media) dalam mengajar yang efektif.

Setiap kegiatan mengajar ditandai dengan adanya beberapa unsur antara lain tujuan, bahan, metode, dan alat (media), serta evaluasi. Unsur metode dan alat (media) merupakan unsur yang tidak bisa dipisahkan dari unsur-unsur lainya yang berfungsi sebagai cara atau teknik untuk mengantarkan bahan pelajaran agar sampai kepada tujuan. Dalam pencapaian tujuan tersebut, peranan media sebagai alat bantu atau alat peraga memegang peranan yang penting, sebab dengan adanya media ini bahan pelajaran dapat dengan mudah dipahami oleh siswa. Selanjutnya Sudjana mengatakan bahwa alat peraga sering disebut audio visual, dari pengertian yang dapat diserap oleh mata dan telinga. Dalam proses belajar mengajar alat peraga (media) dipergunakan dengan tujuan membantu guru agar proses belajar siswa lebih efektif dan efisien.

Bedasarkan uraian-uraian di atas dapat disimpulkan bahwa kedudukan media pendidikan yang merupakan alat bantu mengajar ada dalam komponen metodologi, sebagai salah satu lingkungan belajar yang diatur oleh guru untuk mempertinggi proses interaksi guru dengan siswa dan interaksi siswa dengan lingkungan belajarnya.

Dalam proses belajar mengajar seorang guru hendaknya trampil dalam memilih, menggunakan dan menyesuaikan media yang digunakan. Dalam masalah ini ada beberapa hal yang perlu diperhatikan guru dalam penguasaan pengetahuan tentang media pendidikan untuk mempertinggi kualitas dan efektifitas pengajaran tersebut. Sebagaimana dikemukakan oleh Sudjana (1998); pertama, guru perlu memiliki pemahaman media pengajaran antara lain jenis dan manfaat media pengajaran, kriteria memilih dan menggunakan media pengajaran, menggunakan media sebagai alat bantu mengajar dan tindak lanjut penggunaan media dalam proses belajar siswa. Kedua, guru terampil membuat media pengajaran sederhana untuk keperluan pengajaran, terutama media dua dimensi atau media grafis dan beberapa media tiga dimensi dan media proyeksi. Ketiga, 
guru memiliki pengetahuan dan keterampilan dalam menilai keefektifan penggunaan media dalam proses pengajaran.

Adapun jenis-jenis media pendidikan yang biasa digunakan dalam proses belajar mengajar Sudjana dan Rivai (1997) mengemukakan sebagai berikut; Pertama, media grafis seperti gambar, foto, grafik, bagan atau diagram, poster kartun, komik dan lain-lain. Media grafis sering juga disebut media dua dimensi, yakni media yang mempunyai ukuran panjang dan lebar. Kedua media tiga dimensi yaitu dalam bentuk model seperti model padat (solit model), model penampang, model susun, model kerja, mock up, dan lain-lain. Ketiga, model proyeksi spserti slide, film strips, film, penggunaan OHP dan lain-lain. Keempat, penggunaan lingkungan sebagai media pengajaran.

Adapun indikator-indikator pengetahuan tentang media pendidikan yang harus dukuasai oleh seorang guru ialah : (1) mengetahui ciri-ciri umum media pendidikan, (2) mengetahui cara memilih dan mempersiapkan media pendidikan sederhana seperti gambar, peta dan sejenisnya, (3) mengetahui cara-cara menggunakan media pendidikan pada proses belajar mengajar, dan, (4) mengetahui cara menyesuaikan media pendidikan yang dipakai dengan bahan pelajaran yang diajarkan.

\section{Manfaat Media dalam Pembelajaran}

Hamalik (1986) mengemukakan bahwa pemakaian media pengajaran dalam proses belajar mengajar dapat membangkitkan keinginan dan minat yang baru, membangkitkan motivasi dan rangsangan kegiatan belajar, dan bahkan membawa pengaruh-pengaruh psikologis terhadap siswa.

Secara umum, manfaat media dalam proses pembelajaran adalah memperlancar interaksi antara guru dengan siswa sehingga pembelajaran akan lebih efektif dan efisien. Tetapi secara lebih khusus ada beberapa manfaat media yang lebih rinci Kemp dan Dayton (1985) misalnya, mengidentifikasi beberapa manfaat media dalam pembelajaran yaitu:

a. Penyampaian materi pelajaran dapat diseragamkan.

b. Proses pembelajaran menjadi lebih jelas dan menarik.

c. Proses pembelajaran menjadi lebih interaktif.

d. Efisiensi dalam waktu dan tenaga.

e. Meningkatkan kualitas hasil belajar siswa.

f. Media memungkinkan proses belajar dapat dilakukan dimana saja dan kapan saja.

g. Media dapat menumbuhkan sikap positif siswa terhadap materi dan proses belajar.

h. Merubah peran guru ke arah yang lebih positif dan produktif.

Selain beberapa manfaat media seperti yang dikemukakan oleh Kemp dan Dayton tersebut, tentu saja kita masih dapat menemukan banyak manfaat-manfaat praktis yang lain. Manfaat praktis media pembelajaran di dalam proses belajar mengajar sebagai berikut:

a. Media pembelajaran dapat memperjelas penyajian pesan dan informasi sehingga dapat memperlancar dan meningkatkan proses dan hasil belajar. 
b. Media pembelajaran dapat meningkatkan dan mengarahkan perhatian anak sehingga dapat menimbulkan motivasi belajar, interaksi yang lebih langsung antara siswa dan lingkungannya, dan kemungkinan siswa untuk belajar sendiri-sendiri sesuai dengan kemampuan dan minatnya.

c. Media pembelajaran dapat mengatasi keterbatasan indera, ruang dan waktu.

d. Media pembelajaran dapat memberikan kesamaan pengalaman kepada siswa tentang peristiwa-peristiwa di lingkungan mereka, serta memungkinkan terjadinya interaksi langsung dengan guru, masyarakat, dan lingkungannya misalnya melalui karya wisata. Kunjungan-kunjungan ke museum atau kebun binatang (Azhar Arsyad, 2007).

\section{Kesimpulan}

1. Media merupakan suatu alat atau sarana sebagai perantara untuk menyampaikan bahan pelajaran dari guru kepada anak didik

2. Adapun jenis-jenis media pendidikan yang biasa digunakan dalam proses belajar mengajar sebagai berikut; Pertama, media grafis seperti gambar, foto, grafik, bagan atau diagram, poster kartun, komik dan lain-lain. Media grafis sering juga disebut media dua dimensi, yakni media yang mempunyai ukuran panjang dan lebar. Kedua media tiga dimensi yaitu dalam bentuk model seperti model padat (solit model), model penampang, model susun, model kerja, mock up, dan lain-lain. Ketiga, model proyeksi spserti slide, film strips, film, penggunaan OHP dan lain-lain. Keempat, penggunaan lingkungan sebagai media pengajaran.

3. Adapun indikator-indikator pengetahuan tentang media pendidikan yang harus dukuasai oleh seorang guru ialah : (1) mengetahui ciri-ciri umum media pendidikan, (2) mengetahui cara memilih dan mempersiapkan media pendidikan sederhana seperti gambar, peta dan sejenisnya, (3) mengetahui cara-cara menggunakan media pendidikan pada proses belajar mengajar, dan, (4) mengetahui cara menyesuaikan media pendidikan yang dipakai dengan bahan pelajaran yang diajarkan.

4. Manfaat media dalam pembelajaran yaitu: (1) Penyampaian materi pelajaran dapat diseragamkan. (2) Proses pembelajaran menjadi lebih jelas dan menarik. (3) Proses pembelajaran menjadi lebih interaktif. (4) Efisiensi dalam waktu dan tenaga. (5) Meningkatkan kualitas hasil belajar siswa. (6) Media memungkinkan proses belajar dapat dilakukan dimana saja dan kapan saja. (7) Media dapat menumbuhkan sikap positif siswa terhadap materi dan proses belajar. (8) Merubah peran guru ke arah yang lebih positif dan produktif.

\section{DAFTAR PUSTAKA}

Azhar Arsyad. 2007. Media Pembelajaran. Jakarta: Raja Grafindo Persada.

Depdikbud. 1999. Kamus Besar bahasa Indonesia. Jakarta: Balai Pustaka 
AXIOM: Vol. VII, No. 1, Januari - Juni 2018, P- ISSN : 2087 - 8249, E-ISSN: 2580 - 0450

Hamalik. Oemar. 1992. Psikoligi Belajar Mengajar. Bandung: Sinar Baru.

Rohani, Ahmad H. M. dan Ahmadi, Abu. H. 1990. Pengelolaan pengajaran. Jakarta: Rineka Cipta.

Sudjana, Nana dan Rivai. Ahmad. 1997. Media Pengajaran. Bandung: Sinar Baru.

Sudjana, Nana. 1998. Dasar-Dasar Proses Belajar Mengajar. Bandung Sinar Baru. 